The Philosophical Journal of Conflict and Violence

Vol. II, Issue 2/2018

(C) The Authors 2018

Available online at http://trivent-publishing.eu/

\title{
Ultras in the City. A Sociological Inquiry on Urban Violence in Morocco
}

\author{
Abderrahim Bourkia \\ Moroccan Center of Social Sciences (CM2S), Casablanca, Morocco.
}

\begin{abstract}
Football fandom in Morocco leads to collective actions performed by fan-groups or ultra-groups. Admittedly, this particular type of collective expression reflects young Moroccans' commitment to the values and events of their football team. However, ultra-groups tend to act out with violence, and their actions often cause collateral damage. I first aim to show how ultra-groups help to forge a sense of personal and collective identity in young Moroccans. Then, I refer to the theoretical framework of interactionism in order to explain the reciprocal actions and rivalries between ultra-fans of the Raja Club Athletic (the "Green Boys") and of the Wydad Atbletic Club (the "Winners"). Eventually, I highlight that the collective actions of fan-groups also reflect young Moroccans' concerns regarding social and political issues in their country.
\end{abstract}

Keywords: Interactionism ; Football ; Morocco ; Sociology ; Violence.

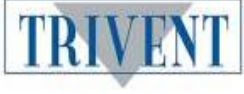

The PJCV Journal is published by Trivent Publishing.

This is an Open Access article distributed in accordance with the Creative Commons Attribution Non Commercial (CC-BY-NC-ND 4.0) license, which permits others to copy or share the article, provided original work is properly cited and that this is not done for commercial purposes. Users may not remix, transform, or build upon the material and may not distribute the modified material (bttp:/ / creativecommons.org/ licenses/by-nc/4.0/) 


\title{
Ultras in the City. A Sociological Inquiry into Urban Violence in Morocco
}

\author{
Abderrahim Bourkia \\ Moroccan Center of Social Sciences (CM2S) \\ Casablanca, Morocco
}

\begin{abstract}
Football fandom in Morocco has led to collective action performed by fan-groups or ultra-groups. Admittedly, this particular type of collective expression reflects young Moroccans' commitment to the values and events of their football team. However, ultra-groups tend to act out with violence, and their actions often cause collateral damage. I first aim to show how ultra-groups help to forge a sense of personal and collective identity in young Moroccans. Then, I refer to the theoretical framework of interactionism in order to explain the reciprocal actions and rivalries between ultra-fans of the Raja Club Athletic (the "Green Boys") and of the Wydad Atbletic Club (the "Winners"). Eventually, I highlight that the collective actions of fan-groups also reflect young Moroccans' concerns regarding social and political issues in their country.
\end{abstract}

Keywords: Interactionism; Football; Morocco; Sociology; Violence.

\section{Introduction}

In Morocco, the phenomenon of "football fandom" and the "ultras" first appeared in 2005. The first two ultras groups were born in Casablanca; the "Green Boys" ultras support the Raja team and the "Winners" ultras support the Wydad team. The "Black Army" fans of the Royal Armed Forces (FAR) of Rabat football team followed suit, and then claimed its status as precursor and flag bearer of the ultra-culture. These details already give us an idea of the tense atmosphere pertaining to the relations between the three clubs and their fans. The rivalry between the clubs of the metropolis and that of the capital have been going on for years. ${ }^{1}$ The ultra-phenomenon will soon become a new means of expression for a large part of the Moroccan society. It will further lead to new forms of local and regional representations. Violence around the stadiums is the most visible part of the ultraphenomenon. The public is aware of this issue as violent incidents involving fans are often related through newspaper articles and TV reports. Especially the "black Sunday game"

\footnotetext{
${ }^{1}$ Derby and classico are synonymous with rivalry between teams and people. In Lens, at the end of the 96-97 season, the "bourgeois" Lille club was mocked by the Lensois who maintained their team in the first division and pushed Lille back to second division. A further example is the opposition between the Celtic football club (Irish-Catholic) and the Rangers (Protestants, Unionists and secular). See Bill Murray "Celtic et Rangers," Actes de la Recherche en Sciences Sociales 103 (1994): 41-51. On the rivalry between Esperance de Tunis and Club Africain, see Franck Moroy, "Football et Politique à Tunis," Correspondances 48 (1997): 10-16. Ricardo Grozio and Mario Flamigni address the topic of derbies in Milan, Genoa and Turin in their paper "Il 'GeMiTo' del derby," in Catenaccio e contropiede. Materiali e immaginari del football italiano, ed. R.Grozio (Rome: Antonio Pellicani, 1990): 139-148.
} 
(2016), in which the Chabab Al Rif Al Hoceimi team opposed Raja Casablanca and ended with the death of three people and more than 80 injured, raising numerous national concerns. Following this tragic event, the ministry of interior decided to ban the activities of ultragroups. A political decision which led to the protests of ultra-fans. In Moroccan media, fans have a bad reputation. Their excessive euphoria and acts of violence are frequently subject to comments and debates. ${ }^{2}$

Phenomena of violence in Moroccan stadiums lead us to the question of the underlying logic of fandom and its members. Indeed, who are these groups of fans and who are the "ultras"? What are their activities? What is their specific role inside and outside of the stadiums? How do fans become violent? What are the specific circumstances of those acts of violence? How are fans precisely acting out with violence? Most importantly, are those who behave violently fans, delinquents or both? How could violence become as trivialized in our society (violence occurring before, during or after the matches)? Do these collective acts of vandalism express a new form of solidarity between perpetrators (who see themselves politically and socially excluded)? What are the ultra-groups doing in order to supervise their members and prevent clashes from resulting in an endless chain of incivilities between their antagonistic groups?

These questions encourage us to go deeper into the analysis of the collective actions of these groups of fans and "ultras". We need to delve into the organization of those groupsthat are running like a "well-oiled"3 machine-and its constitutive elements such as partisanships, festivities, staging of spectacular acts, "tifos," songs, slogans, choreographies, streamers, etc. Asking how fans can become involved in acts of violence is pivotal, and especially since scholars tend to draw distinctions between the violent fan or "hooligan" and fans who join an ultra-group. ${ }^{4}$

Joining a group of fans allows one to appropriate the group's identity. Thereby, the fan builds a new way of life, a sense of belonging. He embodies a collective identity with respect to other fans. Whether he is aware of it or not, his belonging to the group shapes a new image of his social identity (an identity opposed to rival groups, public authorities, companies, and so on).

Fan-groups are at the same time a support for individual and collective identity. As noted by Bernard Poche, identity rests on: "A sociological phenomenon of self-definition that is neither reducible to objective criteria, nor to the individuals' representations of the world outside. However, on the other hand, the phenomenon depends on the representation that individuals have and make regarding themselves." 5 Charles Taylor offers us an even more compelling account on the notion of identity:

... an identity is something that one ought to be true to, can fail to uphold, can surrender when one ought to. More fundamentally, we can see that it only plays the role of orienting us, of providing the frame within which things have meaning for us, by virtue of the qualitative distinctions it incorporates... The condition of there being a thing such as identity crisis is

\footnotetext{
2 See Berangère Ginhoux, Saint-étienne, une ville de football : 'le monde social des ultras', l'imaginaire collectif des supporters de l'asse (Saint-Etienne : Ph.D thesis, 2013).

${ }^{3}$ See Christian Bromberger, Le Match de Football, Ethnologie d'une Passion Partisane à Marseille, Nables et Turin (Paris : Editions de la Maison des Sciences de l'homme, 1995).

4 See Nicolas Hourcade's study "Hooliganisme: Un Phénomène Pluriel," Revue Internationale et Stratégique 94 (2014) : 127-134. See also Patrick Mignon "Supporters Ultras et Hooligans dans les Stades de Football, " Communications 67 (1998) : 45-58. Eventually, see Dominique Bodin, Hooliganisme Vérités et Mensonges (Paris : Editions Sociales Françaises, 1999).

${ }^{5}$ Bernard Poche, "Le groupe territorial et son identité. Le lien social au-delà de la crise du politique," in Identité-Communauté, ed. N. Marouf. Paris: l'Harmattan, 1995.
} 
precisely that our identities define the space of qualitative distinctions within which we live and choose. ${ }^{6}$

In fans, we find a deep sense of belonging which unites individual identities to the collective identity represented by the group. Each fan appropriates the identity of the group. Each fan individually contributes to the collective actions of the group. This process of identification is further developed through the relations to other rival groups. Identification in fans pretty much corresponds to the logic of "primary groups" (in the sense that Sartre and Charles Horton Cooley gave to this concept) where members share intense, frequent and important bonds which make each of them able to have a personalized representation of all the other members of the group. In a nutshell, the "I" immediately refers to a "we" which is opposed to "them" or "the others" (i.e., rival groups or different groups). Charles Horton Cooley was the first to formulate a theory of the "self" constructed in and through relationships to others. ${ }^{7}$ According to him, "primary groups" play a crucial role regarding the formation of identity, personality and collective action. As stated by Cooley: "One lives in the feeling of the whole and finds the chief aims of his will in that feeling." 8 . Primary groups, like the "ultras-groups," are characterized by the existence of intimate relationships of association and cooperation and a sense of unity. The merging of individuals into the collective identity of the group may explain such strong feelings of solidarity. Strong feelings of sympathy and mutual identification are based on "the feeling of the whole." A corollary to the theory of primary groups is that otherness refers to the hostility towards opposing groups. In Marc Augé's words, "Identity and otherness are intimately linked." The same applies to ultra-groups; identity and otherness are inseparable. The concept of otherness completes the identity of the ultra-group insofar as "self-presentation" consists of a "dialogical" process. ${ }^{10}$ In a similar vein than Charles Horton Cooley, Jean-Paul Sartre mentions the "common individual praxis" and highlights that a group is always formed through its opposition to another group. ${ }^{11}$

My study will refer to American ethnomethodology. In this context, I will focus on the question of individual involvement in groups as well as the subjectivity it entails. The group of fans allows identification, stands apart from other ultra-antagonistic groups and facilitates the positioning of "individual" fans. However, the process of group-identification can only be maintained and completed through an "interaction" with rival groups. Hence, my analysis is also based on the theoretical framework of interactionism. These postulates make sense if we consider that the individual and collective awareness of a "we" presupposes an interaction with "them" or "the others"-i.e., with people standing outside the primary group.

\section{I. "Us" and "Them"}

On the pitch, two teams compete. The players run after the ball. In red, players from the Wydadis team wear red soccer jerseys. Players from the Rajawis team wear green soccer

\footnotetext{
${ }^{6}$ Charles Taylor, Sources of the Self (Cambridge: Cambridge University Press, 1989), 30.

7 See for instance Jean-Manuel De Queiroz \& Herbert George Mead, "Sur l'interactionnisme symbolique," in Psycbologie Sociale, Repères Historiques et Principaux Concepts, ed. Mohamed Doraï (Paris : Inpress Editions 2002), 185.

${ }^{8}$ Charles Horton Cooley, Social Organization: A Study of the Larger Mind (New York: Charles Scribner's Sons, 1909), 25.

${ }^{9}$ Marc Augé, La Communauté Illusoire (Paris : Payot et Rivages, 2010).

${ }^{10}$ See Charles Taylor's remarks on the representation of the Other and Otherness in Multiculturalism: Examining the Politics of Recognition (Princeton: Princeton University Press, 1992).

${ }^{11}$ Jean-Paul Sartre, Critique of Dialectical Reason, two volumes (New York: Verso Books, 2009).
} 
jerseys. A referee accompanies the movements, gestures, and actions of the players and the movement of the ball from one player to another. He sanctions, judges, watches for fouls. I guess that this brief description of the match may seem dull to some readers. And yet, it is important to keep in mind that players' juggling, jumping, short and long passes, tackles, all attract the full-attention of thousands of spectators. We are far from imagining what a football game means to them. As noticed by Christian Bromberger: "During the 90 minutes of the match, one can experience all the emotions that someone can feel during his entire lifetime; joy, suffering, hate, anguish, admiration, feelings of injustice."12 What is striking, according to Christian Bromberger and Ludovic Lestrelin, is the way in which one feeling is quickly replaced by another in the course of the game. ${ }^{13}$ Spectators admire the technical gestures of the players, and react to each goal scored or conceded. On the one hand, the audience curses the moment of the conceded goal and loudly complains about the referee's "unfair" decisions. On the other hand, the spectator feasts and rejoices when his team scores goals. Spectators react vividly and spontaneously with words and/or thoughts such as "the referee did not concede this legitimate goal," "the other players are favored by him," "the referee unjustly granted a penalty against our team," "we are stronger than them," and "We scored!" Through such rather common thoughts and expressions, spectators draw a distinction between "us" and "them." At this point, it is worth mentioning Michel Bouet's remark on cooperation and opposition: “... cooperation and opposition, with and against. However, we can also see that the two concepts are closely related; we may even say that they entail reciprocity." 14

This pivotal feature of "cooperation-opposition" also entails its share of victimization. To some extent, we can say that spectators are in osmosis with the players on the green grass. Spectators form two factions that oppose each other, but in a relative state of harmony. However, among these spectators, there is always one group or more that stands out from the others. They are enthusiasts who encourage their team in a specific way. They wear jerseys and scarves of the same color as their team. In order to support their team, they use many means of expression such as rhythmic songs, melodic and expressive slogans, banners. Among many other scholars, Christian Bromberger states that these spectators are the most assiduous in their attendance to football games. They participate at a symbolic staging worthy of a theatrical play. The derby meeting is the clash of two opposite teams. Given that two groups of fans identify with these teams, their clash seems inevitable. Both groups encourage their own team, and mock and depreciate the opponent. Hence, the derby between "Rajawis" and "Wydadis" amounts to an exacerbated rivalry (which is often the case in most derbies around the world). In other words, it amounts to the brutal confrontation between two opposite identities. To be "Rajawi" amounts to show his superiority over the "Wydadi," to intimidate them and vice versa. Such fan-groups are more or less organized, and some of them are commonly called "ultras."

"We" and "the others" are thus opposed in a warlike and tribal context. A context that would be like that of a Greek tragedy in which the reciprocal and conflictual actions are those of the fans. Opposite identities (the "Rajawis" and the "Wydadis") enter conflict; and the stadium is their battlefield. ${ }^{15}$ It is, in Christian Bromberger's words, an "exemplary

${ }_{12}$ Christian Bromberger, Football, la Bagatelle la plus Sérieuse du Monde (Montrouge : Bayard Editions, 1998), 29.

13 Christian Bromberger \& Ludovic Lestrelin, "Le sport et ses publics," in Le Sport en France, une Approche Politique, Economique et Sociale, eds. Pierre Arnaud, Michaël Attali \& Jean Saint-Martin (Paris : La Documentation française, 2008), 113-133.

${ }^{14}$ Michel Bouet, Signification du Sport (Paris : Editions Universitaires, 1968), 52.

${ }^{15}$ Desmond Morris, The Soccer Tribe (New York: Rizzoli, 2016). 
drama." 16 The football match offers fans the opportunity to express themselves. As noticed by Ehrenberg, they have the thirst and rage to appear in public. ${ }^{17}$ They want to move the cameras and the spotlights from the lawn towards the stands. They do their own show. However, Ehrenberg rightly raises the question; why do these fans try to act in such a spectacular way? ${ }^{18}$

These group of fans aim to appear as the most dedicated, the most devoted, and the most loyal group to their team. They want to prove their love to their club to themselves and to others. In this respect, they can use extreme means and travel long distances to attend competitions. Violence in football fans has been much discussed and debated in academic papers and literature, especially in Britain, where the phenomenon is more common. Several studies also addressed the issue of fan violence in Italy and France. In Moroccan academia, violence in football fans has seldom been studied. However, we will see that fans often describe their violent behavior as a kind of reaction against society per se, against its institutions and public authorities which symbolize a repressive state. ${ }^{19}$

In this respect, it is interesting to notice that groups create their slogans, choose their own colors, their flag, their songs and their hymns. In other words, they create symbols that are similar to state-symbols. Groups of fans can be characterized by a "mechanical solidarity" similar to the one Durkheim deduced from his definition of crime:

1. every strongly offended sentiment mechanically determines a passionate reaction; utility of this reaction in maintaining this sentiment. Collective sentiments, being the strongest there are, determine a reaction of the same kind, which is as strong as they are intense...; 2. the collective character of these sentiments explains the social character of this reaction; why it is useful for it to be social; 3. the intensity and particularly the defined nature of these sentiments explain the formation of the determinate organ which enforces this reaction. ${ }^{20}$

Physical or verbal violence is a common practice and an essential activity regarding the functioning of these groups. Violence is even sometimes a "building block" for these groups. ${ }^{21}$ Fans are not necessarily innately violent and can even be non-violent outside of their group. However, they not necessarily refrain from using violence in their groupactivities. How can we explain this violence which seems to go beyond our understanding?

\section{Ultras in the City: in Search of Visibility}

In the world of "football fandom," members no longer lead an anonymous existence. Rather, they exist through their identification with a football team. The mere fact of becoming a fan of Raja or Wydad makes them stand out of the mass. This process guarantees personal visibility to the members of the group who are often in a state of social and economic exclusion. People's lack of social opportunities attracts their attention

\footnotetext{
${ }_{16}$ Christian Bromberger, Football, la Bagatelle la plus Sérieuse du Monde, 13.

17 Alain Ehrenberg, "Le football et ses imaginaires," Les Temps Modernes 460 (1984).

18 Alain Ehrenberg, Le Culte de la Performance (Paris : Fayard/Pluriel, 2010).

19 See Jean François Polo's study "Le stade de football en Turquie au miroir des expressions et mobilisations politiques," in Aux Frontières du Football et du Politique, eds. Thomas Busset and William Gasparini (Bern: Peter Lang 2016), 79-98.

${ }^{20}$ Emile Durkheim, The Division of Labor in Society, trans. George Simpson (Glencoe: The Free Press of Glencoe Illinois, 1960), xiv-xv.

21 The groups make use of what Peter Marsh refers to as "Aggro" (a ritualized staging of violence meant to impress the adversary. See Peter Marsh, Aggro. The Illusion of Violence (London: Dent, 1979).
} 
towards means of success and/or social distinction. ${ }^{22}$ Those who see a fan in the street, know neither his name nor his origin - but the shirt he wears gives him an identity. People do not see him as a young person who comes from a chic or popular district of the white city. They will identify them either as "Rajawi" or as "Wydadi" fans; they may sympathize with them or depreciate them. In the beginning, this search of visibility, this desire to distinguish oneself from the mass, resulted in the creation of ultra-groups. Ultras made their first appearance in Casablanca, in June 2005. The creation of the Ultras Green Boys (GB) can be regarded as the birth-date of the ultra-movement in Morocco. More specifically, the birth-date of the ultra-movement was the match opposing Raja to the Tunisian Star of the Sahel during the African Champions League. "That day, we decided to go to the stadium and install the tarpaulin of our group in the southern corner of the Magana, this was our goal at the start," states a member of the hard-core Green Boys. The tarp gives visibility and, thereby, birth and life to the group. However, in case of theft by another ultra-group, the group will be shattered (i.e., loose its visibility).

A few months later, the ultra-movement in Morocco grow in intensity with the creation of the Winners, that is, the group of Wydad fans. The birth of the ultra-movement reflects the rivalry and competitive spirit between the two teams and their fans. It sheds light on a specific context in which feelings of belonging to groups, and people's affirmation of their individual and collective identities play a crucial role. Ultra-fans commit themselves to a group-identify that stands out from other communities of young fans. ${ }^{23}$ Members of ultragroups are mostly between 13 and 33 years old, and usually gather in either the North Curva (Wydad Frimija) or the South Curva (Magana of Raja). This geographical placement was carried out gradually, as fans were separated on derby day by law enforcement in the middle of the turn and tried to escape south and north behind the goals.

At the Mohammed V stadium, these areas of the stadium are called "Grillage." Fervent fans of the Casablanca giants usually take the cheapest seats. Among them, there are what Bromberger calls "end-of-the-line" fans. These young people see themselves as fans of the cause of their group and their team. With their banners, emblems, and flags, they behave at the same time as real activists and actors. They sing loudly, and shout phrases such as "Death to the opponent!" or "We will massacre this group of homosexuals!"24

They criticize players and accuse referees and members of the committees. In search of visibility and recognition from other rival groups, from those who support the same team, or from the media, ultra fans desperately want to stand out before, during and after the competition. The ultra-groups Raja and Wydad of Casablanca have become gatherings of sociability and affirmation of collective belonging where bonds are forged, and where relationships of symbolic domination between members are forged and dissolved. Both groups of fans compete. Pride and affection for the members of his own group — "we, the group"-are causing clashes with other members and rival fans. These groups allow everyone to join them. Ultra-groups forge people's identity and personality. But, at the same time, the member of an ultra-group participates in the same activities than his peers: making banners, preparing tifos, paying dues, organizing meetings and travels, playing football etc.

\footnotetext{
22 Alain Ehrenberg, Le Culte de la Performance (Paris : Fayard/Pluriel, 2010). See also Patrick Mignon "La violence dans les stades : supporters, ultras et hooligans," Cabiers de l'INSEP 10 (1995), 13-36.

${ }^{23}$ Albrecht Sonntag, Les Identités du Football Européen (Grenoble : Presses Universitaires de Grenoble, 2008).

${ }^{24}$ See for example Christian Bromberger, Le Match de Football, Ethnologie d'une Passion Partisane à Marseille, Nables et Turin (Paris: Editions de la Maison des Sciences de l'homme, 1995); Patrick Mignon, La Passion du Football (Paris: Odile Jacob, 1998) ; Stéphanie Guyon, "Supporterisme et masculinité : l'exemple des Ultra à Auxerre," Sociétés et Représentations 24 (2007) : 79-95.
} 
Those activities and efforts are directed against the opponents who do the same. There is a conspicuous reciprocity between the actions of rival ultra-groups. A collective consciousness gathers fans together around their groups and clubs. It is in a way a collective way of existing which always implies opposition to other groups. Collective and individual identity are displayed through visible signs and symbols which are both an affirmation of a similarity between the members of the group (i.e., the distinctive signs of "we," the people belonging to the group) and an affirmation of difference with respect to "the others" (i.e., those who display other signs and symbols and are "outside of the group"). ${ }^{25}$ Signs and symbols indicate a gap between the two antagonistic groups and entail a process of differentiation regarding the representations of the identity of the individuals who form the groups.

The most dedicated and aware fans of Raja define themselves and distinguish themselves from Wydad fans. It is impossible to imagine the existence of the Raja fan separately from that of the Wyad fan. For instance, in 2013, during the derby between the two Casablanca teams, a large majority of Wydad fans did not attend the match. Of course, due to their absence, the sport show was less appealing for those who attended. The stands that are usually occupied by the rivals were empty. Consequently, the pleasure was no longer there. In France, fans had such a disappointing experience when, during the derby AS SaintEtienne vs. Olympic Lyon and following the decision of the prefects of Loire and Rhone, the Stéphanois fans were forbidden to move to Lyon and fans of the Olympique Lyonnais were forbidden to move to Saint-Etienne. ${ }^{26}$ The presence of the opponent is crucial for the fans. Their oppositions feed and develop collective actions if, and only if, the activities of each group are perceived as interactions. Members of a group act together by means of signs, gestures and songs which are a response to the actions of the other fan-group. Such activities only make sense in the context of interaction. There are conspicuous commonalities between the behavior of fans and Goffman's and Becker's ideas on "interactionism." The theoretical framework of "symbolic interactionism" has been founded by Herbert Blumer and plays an important role in Max Weber's sociology. As stated by Weber: "Subjective attitudes constitute social action only so far as they are oriented to the behavior of others." 27 According to Weber, social actions are actions that the individual performs in relation to the behavior of others. The same applies to ultra-fans.

\section{Violence at the Stadium}

Ultras are different from ordinary fans; they are entirely dedicated to the cause of their team and group. They follow a logique partisane which presupposes hostility towards other individuals and groups. Therefore, violence can play a role regarding social integration and the strengthening of individual and collective identities. Ultra-groups and the use of violence are two inseparable phenomena. "You have to be mean and strong to be an ultrafan," said a member of the nucleus of an ultra-Raja group. Violence is to the group what cement is to the foundations of a house. Violence strengthens the relations between members and comforts them. "At the stadium, I know perfectly well that I can insult who I want without worrying about anyone- the other fans and the police. I am not alone. If I get

\footnotetext{
25 Regarding the logic of reciprocity and differentiation, see also René Girard, Violence and the Sacred (Baltimore: John Hopkins University Press, 1977).

26 Consequently, there were no supporters of ASSE during the derby against Lyon on February 25, 2018 for the $27^{\text {th }}$ day of Ligue 1.

${ }^{27}$ Max Weber, Economy and Society (Berkeley: University of California Press, 1978), 22.

${ }^{28}$ Peter Marsh, Elizabeth Rosser and Rom Harré, The Rules of Disorder (London: Routledge, 1978).
} 
into a fight, there are others who will take my defense and help me out. Whether in the stadium or elsewhere, there is a complicity between us. We are well-united as brothers because we have a common enemy and a common goal," explains a young fan. The majority of fans often define themselves as "hooligans." Moroccan media frequently refers to this word as well.

However, do they really understand what "hooligan" means? Scholars like Bromberger and Bodin showed that hooliganism is defined by the move from a ritualized (Dionysianlike) violence pertaining to the dynamics of the game to a premeditated and organized violence.

In interviews as well as in slogans sung by fans, the term "hooligan" is frequently mentioned. Moroccan media does not use the term "hooligan" in a proper way. For sure, we are sometimes dealing with violent incidents and criminal acts. But, for instance, the English hooligans are people who are trained by gangs. Rival hooligan groups rarely confront each other around stadiums. Rather, they often choose to meet at places where law-enforcement is not likely to see them or intervene (e.g., abandoned places or depots which are far away from the central spots of the city). In Casablanca, violence often occurs just after the matches. Compared to the European continent, the ultra-phenomenon in Morocco has some distinctive features. As I said, violence strengthens the group. At least for some fans, violence also takes the form of a ritual that usually begins with a race in the street to confront rival fans. Police may become a target when it intervenes to prevent an altercation. The fans react, for example, by throwing stones at them (projectiles and smoke bombs are only used in the stadium area); pieces of bricks and concrete blocks are also used. Bodin observes that violence grew in intensity due to a mimetic frenzy (a dynamic that Gustave Le Bon highlighted in his famous book The Crowd: A Study of the Popular Mind). He further argues that feelings of injustice regarding the defeat of one's team had some influence on the fights ${ }^{29}$. This amounts to rationalize violence through the identity of the ultra-group. As noticed by Xavier Crettiez, violence is no longer thought of as an expression of anger or as an unconventional means of political expression. Rather, violence becomes a means of asserting the collective identity of those who act it out. Through this rationalization of violence, the status of those who suffer violence is plainly and simply denied. ${ }^{30}$

\section{Political and Social Themes: The Critique of Morocco's Capital and State-Symbols}

Ultra-fans oppose rival fan-groups but also law enforcement, government, the rich who exploit the poor, and the country. Their hostility is directed towards all symbols of authority. The following statement form a Raja fan is revealing: "We do not want to be controlled by the police, the clubs or their associations. The best thing is to take care of ourselves. Can you imagine a young fan surrounded by an organism that symbolizes some authority? Or imagine a fan encircled by a state that does not grant us the slightest rights?"

Do fans of both clubs share similar angers and concerns? Could it be that the fans share some hatred against the capital Rabat? A shared hatred against the Royal Armed Forces (FAR)? Violent incidents sometimes occur as close as possible to the capital (i.e., in the neighboring city). They sometimes occur in areas of the capital. Sometimes, incidents occur far away from a capital that fans see as domineering. The main team of the capital is

${ }^{29}$ Dominique Bodin, "Préface," in Des ultras dans la Ville, Abderrahim Bourkia (Casablanca: A la croisée des chemins, 2018), 23.

${ }^{30}$ Xavier Crettiez, Les Formes de la Violence (Paris : La Découverte, 2008). 
frequently criticized and mocked in the songs and slogans of both Rajawis and Wydadis fans. FAR fans often chant Raja, the Wydad Casa "wlad lk'bab," which we can translate as "neither Raja nor Wydad, people from Casablanca are sons of bitches." Such slogans have been heard several times when the two teams of Casablanca played the "classico" against the Farawaists. Fans from Casablanca enjoy using the word Farawaists which refers to FAR fans but, at the same time, means "faggot." This double-meaning is an unfortunate coincidence for the fans of this historic club, which was created by the Generals of the Royal Army.

These rivalries and hostilities are not new. Since the 1970s, numerous stories have fueled the animosity of Casablanca fans towards fans of the FAR. For decades now, fans of Raja sing "play Raja, play! The Federation is a pimp."; or, as well, it is alluded that the capital itself is a pimp. Just in passing, it is worth mentioning the moment when the derby contest has been moved to Rabat. Fans of Casablanca have seen the presence of Rabatis on the grandstands as a provocation. The permissiveness and favoritism of law-enforcement regarding people of the capital has often been questioned. "Faraoui ya harbi fel al assima" can be translated as follows: "the defender of the FAR is warlike in the capital." This saying implies that the FAR-movement is protected by the government-especially during its travels. Fans of the club are often seen as fearful, docile, and resigned persons who live behind the barricades of their fancy neighborhoods. Moreover, FAR-fans are depreciated for their constant submission to the government (boukouma). Although the Rajawis enjoy wide popularity in the capital, FAR seems to unjustly benefit from governmental favors. Such animosities are often forgotten or ignored. People generally prefer to focus their attention on the conflicts between fans of Raja and Wydad. However, there is something true about the Arab saying, "me against my brother, me and my brother against my cousin, me, my brother and my cousin against the enemy." For when they fight against fans of the club of the political capital of the country, the violent actions of Casablanca fans go beyond mere matters of sport and almost reach a social and political dimension. French people say that "the enemy of my friend is my friend and the friend of my enemy is my enemy" (l'ennemi de mon ami est mon ami; l'ami de mon ennemi est mon ennemi). This saying expresses the idea of cross-alliances. Indeed, one can notice the cross-alliance of football fans against Rabat, the cold-hearted and monotonous capital of Morocco. Sometimes, football fans' slogans and songs therefore hardly conceal some significant anxieties and concerns in young Moroccans related to issues of unemployment, poverty, exclusion, and lack of social integration. As other young Moroccans, fans feel misunderstood by the government and sometimes dream of fleeing to the Western El Dorado.

Fans from Casablanca denounce the marginalization of their city. They feel economically exploited and socially penalized by a political apparatus that points its finger to the source of social unrest-Casablanca, "A city of rioters." Life there is regularly disrupted by young people from the neighborhoods and the shantytowns that proliferate around Morocco's white city.

However, Casablanca is celebrated in a beautiful and poetic way by fans through their songs. In songs, the city of Casablanca is praised for its independence, freedom, rebelliousness, spirit of challenge, and taste for adventure. In the same vein as Wydad fans, winners of the match often sing "Elfaraoui demdouma," which means "fans of the FAR team are submissive and lamblike." Some fans also sing "[FAR fans are] children protected by and submitted to the government" ("ya wlid elhoukouma") or "You [FAR-fans] do not care about the houma" which means "you FAR-fans never dare to leave your neighborhood." A further song, "Papa Slimane is there" (Baba Sliman Temma) refers to Lieutenant General Hosni Benslimane and the "Fortress" built around Morocco's capital. This reference to the General is likely to challenge conventional-political wisdom of young people from 
Casablanca's neighborhoods. Finally, of all the songs expressing the hostility of fans from Casablanca the FAR, it is worth mentioning the lyrics of the song "ya raby ya al Ali", a song evoking God Almighty. This is specific to Muslim countries and their religious practice of Islam on a daily basis. God is praised and invoked all the time. The Rajawis sing "Magana anti assima" which alludes to their position against the capital, Rabat.

Political tensions reached their climax with the uprisings of the "Arab Spring." Slogans and songs of Casablanca fans became more political and denounced, as usual, the social status quo. Fans of Raja sang their attachment to the monarchy and King Mohammed VI. However, they also pointed out that the government and its ministers are getting rich by pocketing taxpayers' money and looting public funds. The lyrics of the songs have become particularly revealing of the social and political context. "The south magana curva has sharp and poisonous words, [and] hates the government" ("Magana messmouma takrahou elhoukouma"). "We have only one King, Mohammed VI, and the others are thieves who despise us" ("malikouna wahed Mohamed assadiss" or "al baky chefara" / "aina hagara"). "They fill their pockets with the poor's money" ("male kamukara bi flush alfukara"). Lyrics show the fans' willingness to enter political action and to leave an historic trace of the events which shook the Arab world. The willingness to defy authorities is further evidenced by politicallyconnotated symbols. Some fans, display pictures of Che Guevara or the flag of Palestine (by the way, one of the songs of the Rajawi fans states that they are rebels like Che Guevara). ${ }^{31}$ Fans aim to show that insubordination is their true identity.

Political knowledge is, at least most of the time, not very developed in football fans. This is not due to a lack of awareness regarding the current situation of their country. Rather, it is due to the bad image and reputation of political actors. "They come the day of the vote. And after the election campaign, they turn their backs on us and never come back," says a fan from Casablanca. This does not mean that there is no political awareness or will to act in young football fans. From a political perspective, fans and ultra-members adopted many political positions and took part at political activities. The recent consumer boycott campaign in Morocco shows that football fans take part at social protests. The boycott campaign has been raised against the costly dairy products from Danone, Sidi Ali (mineral water) and "Afriquia" (gas stations). This boycott campaign generated strong reactions. Football fans showed their support for the boycott through slogans on the stadiums and graffities on the walls of big cities. Some of them even put graffities of the name of their group on the trucks of the concerned companies. The Fatal Tigers of Maghreb (Fez) launched and signed a petition, thereby continuing their political activities at the Rif (with the "Hirak-movement") and at the Jerada mines. ${ }^{32}$ Fans of Casablanca also voice their political stances. During a match against the Diffaa El Jadida football team, students working at the OFFPT (Office de la formation professionnelle et de la promotion du travail / Center for professional training and promotion of work) were singing: "You do not want us to study... you do not want us to be aware [of our situation]... you do not want us to work... this way, we will be submissive, resigned, easy to dominate and to control." ("mabghitouna nkraw ... mabghitouna nw3aw ... mabghitouna nkbadmou ... bach tbkaw fina t7akmou”).

\footnotetext{
${ }^{31}$ Che Guevara is an iconic figure for football fans. For instance, we find pictures of Che Guevara in ultra-groups from Marseille or in fan-groups from Saint-Etienne.

32 Protesters are claiming for help in order to improve the socio-economic situation of this rather isolated port city in the north-east of the country. The events started on May 30, 2017 following the unsolved death of a fishmonger. Protests in the city of Jerada began after the accidental death of two brothers working in a coal mine. Two events that revive the debate on social divides in the country.
} 


\section{Conclusion}

Football fandom in Morocco has become a means of expression for young people excluded from their society. Wandering and lost young Moroccans join groups that offer them a framework for forging their identities. They join these groups because of their desire to exist and to be recognized by their society. Through these groups, they build a way of life, and achieve a sense of belonging by means of an identity they share with others. Collective actions of fans are usually expressed through visible and audible sings, that is, by means of banners, "tifos" or songs (like the Liverpool F.C fans' song You'll never walk alone).

Ultras' ability to mobilize hundreds or even thousands of fans and to organize demonstrations disturbs Moroccan law-enforcement and government. Recent protests led to the resignation of both Raja and Wydad presidents in 2010 and 2013.

Some may see this social movement as naïve and depoliticized. However, fans' songs, banners, and "tifos" display clear social messages related to unemployment, poverty, exclusion, or contempt for the government. This proves that fans' political awareness does not differ from what was and is currently problematic in Morocco. The mobilization of ultra-groups is a collective action (in its classic meaning). Media commentaries often describe ultras as a social threat. In them, they see the Moroccan embodiment of the "hooligan," a further version of the bellicose English football fan (labelled as "weekend warriors" by the heavy-metal band Iron Maiden). From the perspective of the media, this representation of Moroccan ultras is certainly appealing. And, of course, it is likely to generate big audience-ratings. One thinks about the character of Alex in Stanley Kubrick's A Clockwork Orange. It seems that Moroccan media would like audiences to believe that, like Alex, ultras are just sociopaths interested in theft and rape, and acting within a small gang of thugs. This mediatic representation of the ultra-fans is certainly appealing to lawenforcement and more especially to those who take decisions regarding the country's safety - thereby allowing violations of fundamental public freedoms, turning repression into a watchword, and taking severe measures imported from Europe (which are certainly not adapted to all kinds of societies).

Security measures and prohibitions will only help to save some time in the short run. They do not address the root of the problem (not to mention the lack of technical and human resources). Current approaches are based on the erroneous idea that Moroccan football fandom is synonymous with hooliganism, and that fans only see the stadium as an opportunity to act out with violence. By putting all fans "in the same basket," Morocco's Ministry of Interior is on the wrong target. He chose the easiest way; condemning, once and for all, all kinds collective action from football fans. He made his decisions without considering what the real motivations of some ultras/troublemakers may be. Neither did he take into account the social factors causing the acting out with violence: dysfunctional families, poverty, insecurity, children dropping out of school, lack of the cultural and sportive areas, lack of future prospects. ${ }^{33}$

\section{References}

Augé, Marc. La Communauté illusoire. Paris : Payot et Rivages, 2010.

Bodin, Dominique \& Stéphane Héas. « Anomie sociale et hooliganisme. » In Sports et Violences, ed. Dominique Bodin. Paris : Chiron, 2001

\footnotetext{
33 Norbert Elias \& John Llyod Scotson, The Established and the Outsiders. A Sociological Enquiry into Community Problems (London : Frank Cass \& Co, 1965).
} 
Bodin, Dominique. «Préface. » In Des ultras dans la Ville, Abderrahim Bourkia. Casablanca : A la croisée des chemins, 2018.

Bromberger, Christian. Le Match de Football, Ethnologie d'une Passion Partisane à Marseille, Nables et Turin. Paris : Editions de la Maison des Sciences de l'homme, 1995.

. Football, la Bagatelle la plus Sérieuse du Monde. Montrouge : Bayard Editions, 1998.

Bromberger, Christian \& Lestrelin, Ludovic. "Le sport et ses publics." In Le Sport en France, une Approche Politique, Economique et Sociale, eds. Pierre Arnaud, Michaël Attali \& Jean Saint-Martin, 113-133. Paris : La Documentation française, 2008.

Bourkia, Abderrahim. Des ultras dans la Ville. Casablanca : A la croisée des chemins, 2018.

Cooley, Charles Horton. Social Organization: A Study of the Larger Mind. New York: Charles Scribner's Sons, 1909.

Crettiez, Xavier. Les Formes de la Violence. Paris : La Découverte, 2008.

De Queiroz, Jean Manuel \& Herbert George Mead. «Sur l'interactionnisme symbolique.» In Psychologie Sociale, Repères Historiques et Principaux Concepts, ed. Mohamed Dorai. Paris : Inpress Editions 2002.

Durkheim, Emile. Les Règles de la Méthode Sociologique (1895). Paris: PUF, 1981. The Division of Labor in Society. Translated by George Simpson. Glencoe: The Free Press of Glencoe Illinois, 1960.

Ehrenberg, Alain. "Le football et ses imaginaires." Les Temps Modernes 460 (1984). Le Culte de la Performance. Paris : Fayard/Pluriel, 2010.

Elias, Norbert \& Scotson, John Llyod. The Established and the Outsiders. A Sociological Enquiry into Community Problems. London: Frank Cass \& Co, 1965.

Girard, René. Violence and the Sacred. Baltimore: John Hopkins University Press, 1977.

Goffman, Erving. Les Rites d'Interaction. Paris : Editions de Minuit, 1974.

Guyon, Stéphanie. «Supporterisme et masculinité : l'exemple des Ultra à Auxerre. » Sociétés et Représentations 24 (2007) : 79-95.

Harrison, Paul. «Soccer’s Tribal Wars. » New Society 29 (1974): 602-604.

Hobsbawm, Jean Eric. The Age of Extremes. New York: Vintage Books, 1994.

Hourcade, Nicolas. «Hooliganisme : Un Phénomène Pluriel. » Revue Internationale et Stratégique 94 (2014) : 127-134.

Marsh, Peter. Aggro. The Illusion of Violence. London: Dent, 1979.

Marsh, Peter, Elizabeth Rosser, Rom Harré. The Rules of Disorder. London: Routledge, 1978.

Mignon, Patrick. «La Violence dans les Stades : Supporters, Ultras et Hooligans. » Cabiers de l'INSEP 10 (1995), 13-36. La Passion du Football. Paris : Odile Jacob, 1998.

"Supporters Ultras et Hooligans dans les Stades de Football. » Communications 67 (1998) : 45-58

Poche, Bernard. «Le groupe territorial et son identité. Le lien social au-delà de la crise du politique. » In Identité-Communauté, ed. N. Marouf. Paris : l'Harmattan, 1995.

Smith, Andy. La Passion du Sport. Le Football, le Rugby et les Appartenances en Europe. Rennes : Presses Universitaires de Rennes, 2001.

Sartre, Jean-Paul. Critique of Dialectical Reason. Two volumes. New York: Verso Books, 2009.

Sonntag, Albrecht. Les Identités du Football Européen. Grenoble : Presses Universitaires de Grenoble, 2008.

Taylor, Charles. Sources of the Self. Cambridge: Cambridge University Press, 1989. . Multiculturalism: Examining the Politics of Recognition. Princeton: Princeton University Press, 1992.

Weber, Max. Economy and Society. Berkeley: University of California Press, 1978. 